\title{
Mother Tongue Interference Towards Students' English Pronunciation: A Case Study in IAIN Curup
}

\author{
Leffi Noviyenty ${ }^{1,2, *}$ Mesi Irene Putri ${ }^{1}$ \\ ${ }^{1}$ English Language Education of Institut Agama Islam Negeri (IAIN) Curup \\ ${ }^{2}$ Program Studi Doktor Pendidikan, Universitas Bengkulu \\ ${ }^{*}$ Corresponding author. Email: leffinoviyenty@iaincurup.ac.id
}

\begin{abstract}
Mother tongue interference can affect students' English speaking skill especially in pronouncing the words intrinsically. Considering Rejang language is the dominant mother language used by students at IAIN Curup, the students as EFL learners often use their mother tongue in daily communication and at campus, and Rejang students pronounce English words in a different way. This study investigated the forms of Rejang language interfering students in pronouncing English words, and how they were interfered. This was a descriptive study in the field of English pronunciation elaborated in a qualitative way. Recorded interviews and pronunciation testing were the main techniques of collecting data. Interview guide, validated pronunciation test, and document analysis were the instruments. There were 16 students who used Rejang language in daily communication, and they were incorporated as the subjects of this study. The data analysis adopted Miles and Huberman's model comprising data reduction, data display, and conclusion drawing/verification. The findings revealed that Rejang Language as the dominant students' mother language at IAIN Curup interfered students' English pronunciation across the elements of consonants, vowels, and diphthongs. There were five ways of interference. First, they sounded short vowels into long vowels. Second, they sounded long vowels into short vowels. Third, they changed vowels. Fourth, they changed diphthongs into vowels. Fifth, they changed vowels into diphthongs. However, the interference that influenced English words was only in the dimension of pronouncing English words, while the meanings were still understandable. In conclusion, the interference was positive since Rejang language's phonemic sounds have some similarities to those of English, so this condition does not potentially change the meanings of English words.
\end{abstract}

Keywords: Mother language, Interference, English pronunciation.

\section{INTRODUCTION}

English learning is influenced by several factors, including abilities to acquire the knowledge of English, motivation to learn, age, career goals, time to use English, and English for pleasure [1]. Intelligible and comprehensible factors of English are influenced by basic language skills, including the mother tongue. Mother tongue with different grammar from that of English causes difficulties in learning English. Many errors are found in English learners whose native language has a grammar that is much different from English grammar. These errors are traceable to the grammar factor in mother tongue. Breadsmore [2] said that the impact of the mother tongue can appear in the realms of phonology, lexis, and grammar. The influence of mother tongue can be observed from learners' English productions such as speaking and writing. Hence, learners need to make efforts to reach ideal balance of language mastery between the first language as their mother tongue and English as the other language. Imbalanced mastery of such two languages will lead to distortion. This is known as interference symptoms. According to Francois, "The term interference refers to any difference that may exist between the speech of a monolingual and that of a bilingual" [3][4]. In terms of acquiring a foreign or second language, non-native learners will naturally be confronted with influences that stem from their first languages. Moreover, Noviyenty [5] on her journal concerning the importance of comprehending maternal language interference in teaching and learning processes, the scholars are becoming involved in conversations within the dimension of English as world language with different culture which specialize in intelligibility and comprehensibility and it also needs the teacher roles. The teacher during this condition should drive the scholars by using material design in its diverse cultures. Within the teacher's side, it could assist the teacher in teaching process in order that the 
teachers can teach English language similarly as world interlanguage.

A lot of studies have been done in the field of mother tongue interference. Some of the studies found that Mother tongue interference support English Learning [6][7]. However, other studies concluded that mother tongue gives negative effects in learning English [8][9][10]. In fact, Khan who investigate India mother tongue interference found that there is no impact of mother tongue to English learning [11]. As an archipelago island, Indonesia has thousands of mother languages, including Bahasa Rejang as the mother language of Rejang lebong people, one of districts in Bengkulu Province. The Rejang language is one of the five oldest languages in Indonesia which is used by the Rejang people who live in Bengkulu Province. This language has a unique dialect that is quite difficult to pronounce, and has its own script called Ka Ga Nga. Therefore, most of the Rejang speakers come from the original speaking community, namely the Rejang Tribe. However, as the times developed in the era of globalization, there was a shift towards the use of the Rejang language. There were also found some studies about Rejang Language from several aspect $[12][13][12][14][13][15]$, but not yet in the field of its interference toward English learning, particularly in pronunciation.

Students of English Tadris Study Program at IAIN Curup come from variety of mother languages. From a grand tour observation and students metadata, it is found that there are 10 local languages used among the students. Some of the students communicate in their daily life by using their local languages and some others use their local language occasionally. Those local languages are Java, Rejang, Lembak, Minang, Palembang, Sunda and also Serawai. Serawai are included Manna, Lintang, Semende, Pagar alam and Pasemah with some differences of dialects in the same meaning of words. Moreover, the students who act as EFL learners often use their mother language in their daily communication and at campus. The researcher is interested in investigating whether those students' local languages influence their ability in pronouncing English words and at what word or sounds that they are interfered. This research is important for lecturers in understanding students' problems in pronouncing English words. The students will recognize their problems and they are expected also to pay more attention on the interfered words as their own weaknesses or limitation and then keep trying to overcome them in order to keep pronouncing English words correctly. This study also expectedly contributes to the field of mother language interference which becomes a meaningful learning experience for the students.

\subsection{Mother Language}

The definition of language according to Wibowo [16] is a system of sound symbols that are meaningful and articulated (generated by speech tools) that are arbitrary and conventional, which are used as means of communication by a group of people to produce feelings and thoughts. While an area is a place around or the environment included in a city [17]. From the definition above, it can be concluded that regional language is a symbol or sound that is meaningful and articulate used in the environment of a city or region as a liaison between regions in the territory of the Republic of Indonesia. Local language is part of Indonesian culture that lives in accordance with the explanation of the 45 Constitution which relates to chapter XV article 36. Regional language is a traditional language in an area which has been inherited from generation to generation to the speaking community where the language is spoken. Mother tongue is a language established from a communicative habit of a group of people, and the surface structure of that language becomes their first language. Grounded in the perspective of lingua-culture, the role of mother tongue in the use of a foreign or second language can lead to both positive and negative impacts [19]. To be specifically identified, Not only does mother tongue represent codes someone acquires from his mother, but it also refers to a prevailing language used by most of the people in the community he is engaged into. In other words, mother tongue is also known as a native language [20].

Moreover, Bloomfield asserts mother tongue which is learnt by human is named native language. Children from a certain group of community, since they were born, have gradually learned to acquire a language from their mothers in a natural way. This is the so-called mother tongue, and this language is continuously passed across generations [21]. Such a mother tongue is always affiliated with the culture which prevails in a certain community. Therefore, diverse groups of community may have diverse mother tongues. A language community is commonly also associated with a certain region. Thus, it is natural that people of diverse regions have different mother tongues as well.

\subsection{Interference}

Interference is that the language errors which occur when mother tongue elements are brought into the language which is being learned. According to Lott, interference indicates the forms of errors encountered in one's non-native language, and such errors can be identified by probing into his mother tongue [22]. In a similar concept, Ellis elucidated that interference draws on a linguistic transfer, in which it refers to the influence that the learner's first language exerts over the acquisition of a second language [23]. He opined that such a transfer occurs due to what a learner perceives of what could be transferred from his first language to the other language, and such a transfer also happens by virtue of the learner's linguistic development that stems from his efforts of learning a second or foreign language. Mother language or L1 is the mother tongue, which is learned and used since childhood in the family; while L2 is a language that is only then learned, namely after mastering $\mathrm{L} 1$. If the mastery of $\mathrm{L} 1$ is better than $\mathrm{L} 2$, and 
also the opportunity to use it is wider, there is a possibility that the speaker's L1 will affect his L2. This influence can be in the form of events called interference both at the phonological, morphological, syntactic, and lexicon levels. How much the influence L1 has on L2 depends on the level of authority over L2. Second language teaching experts believe that the first language or a previously acquired language affects the students' second language acquisition process. Even the first language has long been considered a bully for students to master the second language. This view was born because consciously or not, students make transfers or move the first language element into that of the second language. As a result, there is what is called a change in structure and language codes from the first language to the second language used. If there is a great extent of similarity between students' first language and the second or the other language they learn, they will find it easier to work with a linguistic transfer. If the difference between the two is not realized by students, there is a possibility that it will be negative, which in turn will cause interference (deliberately using the rules of the first language for the second language). That is why, the greater the difference in structure between that in the first language and that in the second language, the effort that students must make in acquiring and mastering the second language tends to be heavier and more difficult when compared to if the two languages have in common. Thus it can be seen that the process of acquiring a second language is affected by the first language. The first language's influence on the learning process of a second language can also be observed from what has become known as the term intermediate language. Intermediate language is a symptom of language use that arises as a result of students not being able to completely leave their habits in the first language, but not yet fully mastering the second language.

Many scholars view mother tongue's interference as the impact of a mother language in the a structural dimension which subsumes some elements ranging from audio-visual, audio-global, and structural-global elements [24]. Dulay elucidates that an interference of a language is a linguistic case that continuously receives diverse viewpoints in linguistic studies [25]. In a certain case of mother tongue's interference, a learner applies his knowledge or competence of the first language during learning the second or foreign language. As the foregoing, language interference takes place across linguistic domains from phonetics, morphology, syntax, and other forms of language structures [26]. Nonetheless, learners will find it difficult if language interference occurs in the dimension of a great extent of diverse parallelisms between their first and second (or foreign) language [27].

In a number of expanding circle countries whose English educational system teaches the learners English as a foreign language, the taught English per se is not really oriented towards the essence of English as a mode of social interactions. English likely seems to be taught in a way that is central to structures. In such a way, a problem then strikes learners especially when the characteristics of their first languages are so much different from those of English. As a result, learners incline to make use of their first language structures when they are using English. In so doing, the case of language interference happens. There are three forms of language interference according to Weinreich. They cover phonological, lexical, and grammatical interference [28]. Phonological interference is related to the first language of foreign language students which is affected the sound production of the target language. In the aspect of phonological interference, it is associated with a condition that a second or foreign language user makes use of his first language sounds. Physically different from one another in a very number of the way, like place of articulation, manner of articulation, voicing, and tongue height [29]. Because the result, the sound production would cause misunderstanding, miscommunication and frustration. English has become an issue within the majority of colleges in Indonesia and students tend to own some problems at the instant of articulate English sounds because of the phonological interference.

Pronunciation simplifies organized sounds of language produced by human speech organ using all the phonemics units of the language as well, which is maintaining all the phonemic units of the language by means of the distinctive units of the distinctive phonemic features [30]. Simply speaking, pronunciation is a means someone makes use of phonetic and phonemic rules such as phonemes, intonations, rhythms, and other related components in articulating words or linguistic codes [31].

\subsection{English Phonetic Alphabet and Pronunciation Transcription}

Pronunciation is the way in which a word is pronounced in a way that can be understood by others [31]. In its pedagogy, the objective of teaching pronunciation is to assist students in intelligible communication. Pronunciation teaches learners how to pronounce the words according to their sound not their spelling in order to sound more natural and to make our words better understood [32]. Students who learn English as a second or foreign language bring with them their first language concept. A problem emerges when many students face difficulties because the sounds of phonemes and phonetic systems in English are different from those of their first languages. As a result, students still use phonemic sounds and phonetic systems of their first languages when they are sounding or uttering English. Hence, English pronunciation learning should ideally fulfill a necessary element regarding the practices of sounding English phonemes and uttering or articulating English properly.

In reading a word in English, the phonetic transcription is often presented in a written from between slashes. For instance, the phonetic transcription of morpheme "word" is written in the form of $/ \mathrm{w} 3 \mathrm{~d} /$. Phonetic transcription is constructed resting upon the International Phonetic Alphabet (IPA) which provides systemized symbols of English phonemes. However, many students do not recognize those symbols [33]. Fortunately, online dictionaries today have provided a 
feature of English sounds which can be listened anytime as the users need. The researcher also use Google translate to re-check the transcription, however, in written form of report, the phonetic symbol should be used to describe how a word is pronounced.

In English phonetic alphabet, there are vowels, consonants and diphthongs [34][35][36]. Vowel is phonemic sounds produced by shaping the mouth cavity especially in the area above the tongue. There are 5 main vowels in English: /a/, /e/, /i/, /o/, /u/ and one special vowel /y/. Words such as "only", "quickly", "bicycle", are examples of $/ y /$ sounds vowel, while "yellow", "yesterday", are /y/ sound consonant. Consonant is the phonemic sounds which are produced by restricting the air stream within the mouth so that certain consonant sounds are produced [37][38]. English possesses 21 kinds of consonant. Diphthong is a vowel with two different targets: that is the tongue (and/or other part of speech articulation) moves during the pronunciation of the vowel. There are 8 common diphthongs in English: /av/ as in "town", /ai/ as in "light", /ei/ as in "play", /eə/ as in "pair", /iə/ as in "deer", /ov/ as in "slow", / $\mathrm{j}$ / as in "toy", /və/ as in "sure" [33].

Interference in the aspect of phonology occurs a speaker of two languages produce phonemic sounds of the first language across the second language while using the second language [39]. Justice [40] asserts "There is not a perfect correspondence between spelling and sounds in English". Despite being available in all languages, vocal and consonant sounds, the so-called segmental sounds, have diverse variety across different languages. In terms of learning English, students are called to produce such segmental sounds in properly in order to make ideal meanings as desirable during spoken communication using English. Justice in Chaira [40] accentuated that to reach a native-like competence, all students are demanded to get engaged into practices of listening and sounding or pronouncing English in an ideal manner.

A lot of studies have been done in the field of the influence of the mother language on second language learning. One of which is research conducted by Manrique [41] at a public university in Colombia. This study is done to see the influence of language mother on English usage. The results of this study indicate the negative influence of language Spanish as the Mother tongue in English produced by the informant. That mistake mostly found at the phonological level and grammar. In the phonological level there is one sound that is often found lost in English pronunciation, which is influenced from habits when using his mother tongue. On the grammar of the Spanish language influence indicated by omitting the subject of the sentence which in Spanish does not affect the meaning of the sentence, while in English, this is a mistake.

The influence of mother tongue at the phrase level discussed in the article written by Thyab [42]. This paper analyzes errors use of article in English writing by learners who have Arabic as the mother tongue. This error was caused of a difference in the article system of the two languages, especially on the definite system and indefiniteness of articles in English ones not found in Arabic. In Arabic Language, articles are classified by type and the amount of an item.

A study of influence of mother tongue in rural areas in Sarawak, Malaysia written by Suliman shows clearly the negative influence of mother tongue on learning English. English ability is an important thing in Malaysia because with the number of ethnic groups who live in Malaysia, English is a means of communication in the world of business, social interaction and one language international use in Malaysia. The research was conducted on students from two schools in Sarawak. The students as respondents were examined their ability in speaking English. The result of the research shows that there are errors in morphology and syntax. Negative effect of mother tongue can be observed clearly because it is in deep speaking, the respondent translated his mother language into English [43].

Fitri Aulia was doing a research on mistakes made by students in Minangkabau when transferring their Mother language into English. The mistakes were caused by the students' background culture, error in selecting words, grammatical interference from their mother language [44]. In fact, those mistakes did not influence English grammatical rules. The interference of mother language also happened in phonology aspect, vocabularies and structure [45].

This research investigates mother language interference, in this study is Rejang Language, toward students' English pronunciation and uses phonology aspect to elaborate the result.

\section{RESEARCH METHOD}

This is a descriptive study in the field of English pronunciation, particularly phonological interference, which is elaborated in qualitative way. Recorded interview and pronunciation testing are the main techniques of collecting data. Interview guide, validated pronunciation test and document analysis are the instruments. All students who come from different mother languages and use their mother languages in daily communication are the subjects of this research. The subjects of this research are 16 students of English students who use Rejang Local Language in their daily life, the highest amount of local language used in IAIN Curup. This study uses Miles and Huberman theory which consists of data reduction, data display and conclusion drawing/verification, in analyzing the data.

\section{RESEARCH FINDINGS AND DISCUSSION}

\subsection{The Form of Mother Tongue Interference}

From recorded script read by students and interview, it is found that the words interfered by Rejang Language as students' mother language are as in Table 1. The table accounts for a couple of words which receive interference from students' mother tongue, the so-called Rejang language. 
Table 1. The Interference of Rejang Language in

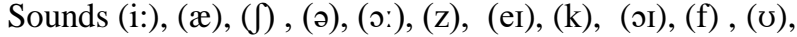
$(\Lambda),(ð),(\mathrm{I}),(\partial \mho),(3:)$

\begin{tabular}{|c|c|c|c|c|}
\hline No & Word & $\begin{array}{c}\text { The } \\
\text { correct } \\
\text { pronunci } \\
\text { ation }\end{array}$ & $\begin{array}{c}\text { The } \\
\text { subject } \\
\text { interferen } \\
\text { ce }\end{array}$ & $\begin{array}{c}\text { The } \\
\text { sounds } \\
\text { change }\end{array}$ \\
\hline 1 & Pea & /pi:/ & /pi/ & $\begin{array}{l}\text { Vowel - } \\
\text { short } \\
\text { vowel }\end{array}$ \\
\hline 2 & Slab & /slæb/ & /sl3:b/ & $\begin{array}{l}\text { Vowel- } \\
\text { long vowel }\end{array}$ \\
\hline 3 & $\begin{array}{l}\text { Wedn } \\
\text { esday }\end{array}$ & $\begin{array}{l}\text { /'w3:nzd } \\
\text { eI/ }\end{array}$ & //wednesdo & $\begin{array}{l}\text { Diphthong } \\
\text { - vowel }\end{array}$ \\
\hline 4 & Go & /gəo/ & $/ \mathrm{go} /$ & $\begin{array}{l}\text { Diphthong } \\
\text { - vowel }\end{array}$ \\
\hline 5 & Kids & /kIds/ & /ki:ds/ & $\begin{array}{l}\text { Vowel - } \\
\text { long vowel }\end{array}$ \\
\hline 6 & $\begin{array}{l}\text { Plasti } \\
\text { c }\end{array}$ & /plæstIk/ & /pla:sti:k/ & $\begin{array}{l}\text { Vowel }- \\
\text { long vowel }\end{array}$ \\
\hline 7 & For & $/ \mathrm{f \partial}(\mathrm{r}) /$ & /fpr/ & $\begin{array}{l}\text { Vowel }- \\
\text { different } \\
\text { vowel }\end{array}$ \\
\hline 8 & $\begin{array}{l}\text { Broth } \\
\text { er }\end{array}$ & /’br^ðə/ & /bra:de(r)/ & $\begin{array}{l}\text { Vowel }- \\
\text { long vowel }\end{array}$ \\
\hline 9 & Spoon & /spon/ & /sppn/ & $\begin{array}{ll}\text { Vowel } & - \\
\text { different } & \\
\text { vowel }\end{array}$ \\
\hline 10 & From & $/ \mathrm{fr} \wedge \mathrm{m} /$ & /from/ & $\begin{array}{ll}\text { Vowel } & - \\
\text { different } & \\
\text { vowel }\end{array}$ \\
\hline 11 & Toy & /tor/ & /twi:/ & $\begin{array}{l}\text { Diphthong } \\
- \text { different } \\
\text { diphthong }\end{array}$ \\
\hline 12 & $\begin{array}{l}\text { Statio } \\
\mathrm{n}\end{array}$ & $/ /$ steIf(ə)n & /stei:tfen/ & $\begin{array}{l}\text { Vowel- } \\
\text { long vowel }\end{array}$ \\
\hline 13 & Store & /sto:/ & /stur/ & $\begin{array}{l}\text { Vowel- } \\
\text { different } \\
\text { vowel }\end{array}$ \\
\hline 14 & Please & /pli:z/ & /plis/ & $\begin{array}{l}\text { Vowel - } \\
\text { short } \\
\text { vowel }\end{array}$ \\
\hline 15 & Fresh & /fres/ & /vrei:s/ & $\begin{array}{l}\text { Vowel - } \\
\text { diphthong }\end{array}$ \\
\hline 16 & $\mathrm{Bag}$ & /bæg/ & /beig/ & $\begin{array}{l}\text { Vowel - } \\
\text { diphthong }\end{array}$ \\
\hline 17 & And & /ænd/ & / ond/ & $\begin{array}{l}\text { Vowel - } \\
\text { short } \\
\text { vowel }\end{array}$ \\
\hline 18 & Train & /treIn/ & /trei:n/ & $\begin{array}{l}\text { Diphthong } \\
\text { - long } \\
\text { diphthong }\end{array}$ \\
\hline 19 & Snack & /snæk/ & /senæk/ & $\begin{array}{l}\text { Vowel - } \\
\text { add vowel }\end{array}$ \\
\hline 20 & Snake & /snerk/ & /snek/ & $\begin{array}{l}\text { Diphthong } \\
\text { - vowel }\end{array}$ \\
\hline
\end{tabular}

The interference is associated with the sound of (i:) as a long vowel sound placed in the front area. It is identical to a long vowel because it is articulated in a slightly longer duration than generally short vowels. In terms of physical difference, the height of tongue while sounding (i:) should be higher than that of (I). Lips should be shaped slightly widely like a little bit smiling when producing the sound of (i:). When students are dealing with the sound of (i:), some of them found it challenging and later on failed to sound it properly. They sounded this phoneme in a shorter duration as if sounding the short (I). Subsequently, they seemed to change the sound of (ae) into (3:) when pronouncing the word "slab".

The (I) sound is made in the front part of the mouth with closed position. This indicates that when the phoneme (I) is sounded, the tongue's front area is made heightened towards the mouth's upper part in a way that slightly spread the lips. However, the tongue's front area is not positioned too high as it touches the upper part of the mouth. It should be positioned just slightly down proximate to the quality of the close mid vowel. When sounding the phoneme (I), some students faced a problem. They produced the short vowel sound in the form of a long vowel sound similar to (i:) produced in a close, central, unrounded manner.

Subsequently, the phoneme of (ei) is categorized as a diphthong articulated in a slightly closed manner. It draws on that the production of this phoneme is begun with an open position of vowel and ended with a nearly closed position of vowel. Such a diphthong begins to be sounded with the sound of phoneme (e), and it is made gliding to the phonemic sound of (i). As encountered amid several students, the phonemic sound of this diphthong was articulated in a way of sounding the phoneme of (ə) schwa. The phoneme of ( $\partial$ ) is positioned in the mid and central vowel. This phoneme is articulated by raising the tongue's center halfway in the middle of open and closed areas of vowel. Anchored in the International Phonetic Alphabet, the phoneme (ə) can only be produced with a weak syllable, and oftentimes it is not sounded. Amongst the students, the problem found concerning such two sounds of phonemic vowels was that they replaced one with the other. When they sounded the phoneme (ə), they found it quite difficult because this phonemic sound is not found in the Rejang language's phonemic systems and even in the Indonesian language systems. The way to pronounce this sound is to open the mouth wider. Such kind of substitution is found in the medial position of the word "Wednesday".

The interference also occurred when students articulated the phonemic sound of $(\delta)$ that was replaced by the sound of phoneme (s). The phoneme $(\delta)$ basically falls into a palatal, voiceless, and fricative sound. The palatal, voiceless, and fricative elements should be fulfilled when articulating the phoneme $(\delta)$. The students articulated the palatal-ridge phoneme $(\delta)$ in the position of alveolar ridge. As a result, the students articulated the sound identical to alveolar, voiceless, and fricative domains. The replacement from phoneme (s) to phoneme 
( $\int$ took place in initial and medial positions. The medial replacement or substitution was found in the articulation of the word "fresh" /fre $/$. The sound (s) replaced the position of the medial $(\delta)$ sound so that the morpheme "fresh" was articulated into /frei:s/. The substitution from $(\delta)$ to (s) in the medial position happened to one phonological environment. This case was identifiable from students" pronunciation of word "fresh" pronounced /frei:s/.

Furthermore, the phoneme (əひ) is classified into a closing diphthong. This phoneme begins with an open position of vowel and ends with a closed position of vowel. Such a diphthong was begun by articulating the sound of (ə) and ended by sounding the phoneme ( $v)$. As revealed, students found a problem of pronouncing the diphthong ( $\partial \mho)$ during the research. They did not sound it with the ending of $(\mho)$ instead of $(0)$.

The phoneme $(\Lambda)$ is sounded in an open-centralvowel position. Articulating the phoneme $(\Lambda)$ works in the tongue's center. Nonetheless, the phoneme $(\Lambda)$ does not fall into a completely open vowel. The tongue's center is slightly raised proximate to the area of openmid-vowel sound. The students articulated the $(\wedge)$ phoneme by directing it towards the sound of (o) as seen in the word "from".

\subsection{The Way They Were Interfered}

The finding shows that there are there are five ways of interference. First, they sound short vowels into long vowels, for example in pronouncing the following words:

\begin{tabular}{|l|l|l|}
\hline $\begin{array}{c}\text { English } \\
\text { Words }\end{array}$ & \multicolumn{1}{|c|}{$\begin{array}{c}\text { English } \\
\text { Pronnciation (IPA) }\end{array}$} & $\begin{array}{c}\text { Students } \\
\text { Mother Tongue }\end{array}$ \\
\hline Slab & /slæb/ & $/ \mathrm{sl3:b/}$ \\
\hline Kids & /kIds/ & /ki:ds/ \\
\hline Plastic & /plæstIk/ & $/$ pla:sti:k/ \\
\hline
\end{tabular}

Second, they sound long vowel become short vowel, as in the following:

\begin{tabular}{|l|l|l|}
\hline $\begin{array}{c}\text { English } \\
\text { Words }\end{array}$ & \multicolumn{1}{|c|}{$\begin{array}{c}\text { English } \\
\text { Pronnciation (IPA) }\end{array}$} & $\begin{array}{c}\text { Students } \\
\text { Mother Tongue }\end{array}$ \\
\hline And & /ænd/ & $/$ ond/ \\
\hline Please & $/ \mathrm{pli}: \mathrm{z} /$ & $/ \mathrm{plis} /$ \\
\hline Pea & $/ \mathrm{pi} / /$ & $/ \mathrm{pi} /$ \\
\hline
\end{tabular}

Third, they change vowel sound.

\begin{tabular}{|l|l|l|}
\hline $\begin{array}{c}\text { English } \\
\text { Words }\end{array}$ & \multicolumn{1}{|c|}{$\begin{array}{c}\text { English } \\
\text { Pronnciation (IPA) }\end{array}$} & $\begin{array}{c}\text { Students } \\
\text { Mother Tongue }\end{array}$ \\
\hline Spoon & $/$ spun/ & $/ \mathrm{sppn} /$ \\
\hline From & $/ \mathrm{fr} \Lambda \mathrm{m} /$ & $/ \mathrm{from} /$ \\
\hline For & $/ \mathrm{fə}(\mathrm{r}) /$ & $/ \mathrm{fpr} /$ \\
\hline
\end{tabular}

Fourth, they change diphthong to vowel and fifth,

\begin{tabular}{|l|l|l|}
\hline \multicolumn{1}{|c|}{$\begin{array}{c}\text { English } \\
\text { Words }\end{array}$} & \multicolumn{1}{|c|}{$\begin{array}{c}\text { English } \\
\text { Pronunciation } \\
\text { (IPA) }\end{array}$} & $\begin{array}{c}\text { Students Mother } \\
\text { Tongue }\end{array}$ \\
\hline Snake & /snerk/ & /snek/ \\
\hline Wednesday & $/$ 'w3:nzdeI/ & $/$ wednesdə/ \\
\hline go & /gəo/ & $/$ go/ \\
\hline
\end{tabular}

Fifth, they change vowel sound become diphthong.

\begin{tabular}{|l|l|l|}
\hline $\begin{array}{c}\text { English } \\
\text { Words }\end{array}$ & \multicolumn{1}{|c|}{$\begin{array}{c}\text { English } \\
\text { Pronunciation (IPA) }\end{array}$} & $\begin{array}{c}\text { Students } \\
\text { Mother Tongue }\end{array}$ \\
\hline Bag & /bæg/ & /beig/ \\
\hline Fresh & $/$ fre $/$ & /frei:s/ \\
\hline
\end{tabular}

\section{CONCLUSION AND SUGGESTIONS}

Rejang Language as the dominant students' mother language at IAIN Curup interferes the sounds when the students are pronouncing English words related to the elements of consonants, vowels, and diphthongs. There are five ways of interference extending to (1) pronouncing short vowels into long vowels, (2) pronouncing long vowels into short vowels, (3) changing vowels, (4) pronouncing diphthongs into vowels, and (5) pronouncing vowels into diphthongs. However, students' mother tongues interfere with the sounds in pronouncing the words, while the meanings are still understandable. To sum up, the interference is positive since Rejang language's phonemic systems have some similarities to that of English, and this condition does not potentially change the meanings of English words.

It is suggested that students who have strong mother tongue interference which influence the meaning of English vocabularies to always practise the improvement of their pronunciation in order to pronounce English words correctly. It is also expected that English teachers could pay more attention to help their students overcome the interference of their students' mother tongue particularly if the interference influence the meaning of English words.

\section{AUTHORS' CONTRIBUTIONS}

All authors contributed equally to the preparation of the paper. Since Indonesia is an archipelago that consists of thousands of islands and each island consists of many regions and provinces, Indonesia has a lot of mother languages or local languages which also act as the character of each region. This study gives an analysis of special character of the local language in Indonesia namely Rejang Language as one of five old mother languages in Indonesia.

\section{ACKNOWLEDGMENT}

We would like to take this opportunity to thank the following persons for the effort and expertise:

1. Dr. Rahmat Hidayat, M. Ag., M. Pd., Rector of State Institute of Islamic Studies (IAIN) Curup

2. Dr. Fakhruddin, M. Pd. I., Director of Postgraduate Program of IAIN Curup.

3. Jumatul Hidayah, M. Pd., Head of English Tadris Study Program IAIN Curup

4. All English Lecturers of IAIN Curup

\section{REFERENCES}

[1] M. F. Latu, "Factors Affecting The Learning of English as A second Language Macroskills Among Tongan Secondary Students," 1994, [Online]. 
Available: http://ro.ecu.eu.au/theses/1110.

[2] H. B. Breadsmore, Bilingualism: Basic Principles. Tieto: Avon, 1982.

[3] F. Grosjean, Life With Two Languages. USA: Harvard University Press, 1992.

[4] M. Swan, "The Influece of Mother Tongue on Second Language Vocabulary Acquisition and Use.," 2008.

[5] L. Noviyenty, "The Paradigms of Teaching English Across Cultures: EFL Teachers' Perspectives," IJCI, vol. 12, 2020.

[6] A. Davud, K., and Molood, "Azerbaijan, Turkic Speaking English Language Teachers' Attitude Towards tehUse of their Students' Mother Tongue in English Classes.," Int. J. Research Study. Lang. Learn., vol. 3, no. 3, pp. 55-72, 2014.

[7] H. Kafes, “A Neglected Resource or Overvalued Illusion: L1 Use in the Foreign Language Classroom," Int. Jpurnal New Trends Educ. Their Implic., vol. 2, no. 2, pp. 128-140, 2011.

[8] Larsen - Freeman, Techniques and Principles in Language Teaching. 2nd Edition. Oxford: Oxford University Press, 2000.

[9] C. Chaudron, Second language Research: Research on Teaching and Learning. Cambridge: Cambridge University Press, 1988.

[10] G. Mamo, "Mother tongue interference into learning English as a foreign language: Analysis of Afan Oromo interference into learning EFL, orthography and pronunciation (A case of Batu secondary school)," J. Lit. Lang. Linguist., vol. 26, pp. 95-106, 2016.

[11] A. M. R. Khan, R. Shaheen, and S. Muhammad, "Impact of Mother Tongue on Learning English Language on Secondary School Level Students," J. Lit. Lang. Linguist., vol. 31, pp. 15-18, 2017.

[12] T. P. Lestari, U. D. Bengkulu, and B. Rejang, "Kamu," vol. 7, pp. 76-84, 2019.

[13] T. Mahnunah and N. P. Putri, "BAHASA SIMALUNGUN DAN BAHASA REJANG ( PERSPEKTIF Komparatif, Linguistik Historis)," vol. 01, no. 2113 168, 2018.

[14] Y. Paulina, "KATA SAPAAN DALAM BAHASA REJANG DIALEK LEBONG," LATERALISASI, vol. 7, no. 1, pp. 44-55, 2019.

[15] dan M. S. S. Rita Tiara Aryani1, Irma Diani2, "PEMEROLEHAN KOSAKATA BAHASA REJANG ANAK SEKOLAH TAMAN KANAKKANAK PEMBINA MERIGI KABUPATEN KEPAHIANG: KAJIAN PSIKOLINGUISTIK," KORPUS, vol. I, pp. 173-181, 2017.

[16] W. Wibowo, Manajemen Bahasa. Jakarta: Gramedia, 2001.

[17] W. P. Darminto, Kamus Bahasa Indonesia. Jakarta: Balai Pustaka, 1993.

[18] jos D. Prera, Leksikon Istilah Pembelajaran Bahasa: Bahasa-Istilah dan UngkapanLeksikologi. Jakarta: Gramedia Pustaka, 1989.

[19] D. Careless, "Students Use of The Mother Tongue in the Task-based Classroom," ELT J., vol. 62, no.
4, pp. 331-337, 2008

[20] E. N. Denizer, "Does Mother Tongue Interfere in Second Language Learning?," J. Foreign Language Educ. Technol., 2017.

[21] L. Bloomfield, Language. London: Great Britain, 1933.

[22] D. Lott, "Analyzing and Counteracting Interference Errors," ELT J., vol. 37, no. 3, pp. 256-261, 1983.

[23] R. Ellis, The Study of Second Language Acquisition. New York: Oxford University Press, 1997.

[24] Lekova, "Language Interference and Methods of its Overcoming in Foreign Language Teaching.," Fac. Educ. Trakia Univ. Stara Zagor. Bulg., 2009, [Online]. Available: http://www.uni-sz.bg.

[25] S. Dulay, H., Burt, M., and Krashen, Language Two. New York: University Press, 2009.

[26] J. G. Negeri, "Interference: Its Role in The Target Language Mastery to Indonesian Learners," Univ. Nur Arifin, vol. 4, no. 1, 2011.

[27] Mufeed Jadallah, "A Review of Some New Trends in Using L1 in the EFL Classroom," Al Quds Open Univ., 2013.

[28] U. Wenreich, Language in Contact. New York: Mouton Publisher, 1968.

[29] M. S. Carlos, J.J., \& Karina, "Mother Tongue Phonological Interference in English Language Speech," AAHS J. Tech. Univ. Cotopaxi, 2016.

[30] W. labov, Some Sociolinguistics Principles. Wiley - Blackwell, 2003.

[31] O. Deterding, "Spelling Pronunciation in English," ELT J., vol. 7, no. 1, pp. 87-91, 2016.

[32] Celce-Murcia et al, Teaching Pronunciation:A Course Book and Reference Guide. Cambridge: Cambridge University Press, 2010.

[33] U. Gut, Textbook in English Language and Linguistic: Introduction to English Phonetics and Phonology. German: Peter Lang, 2009.

[34] D. Odden, Introducing Phonology. New York: Cambridge University Press, 2005.

[35] "Vowels and IPA Symbols."

[36] "Diphthongs."

[37] W. Stevens, Phonetics: The Sounds of Language. Amazon: Palgrave Masmillan, 2009.

[38] Cook Ann, American Accent Training Second Edition. New York: Matrix Press, 2000.

[39] L. Chaer, Abdul and Agustina, Sosiolinguitik Perkenalan Awal. Jakarta: Rineka Cipta, 2004.

[40] P. Justice, Relevant Linguistic: An Introduction to the Structure and Use of english for Teacher. Stanford: CSLI Publication, 2004.

[41] C. M. Manriques, "Mother Tongue Interference with Foreign Language: A Case Study about A2 Oral Production in olombian Public University.," Open. Writ. Doors Journals, vol. 9, no. 1, 2012.

[42] R. Abid Thyab, "Mother-Tongue Interference in the Acquisition of English Articles by L1 Arabic Students," J. Educ. Pract. , vol. 7, no. 3, pp. 1-4, 2016, [Online]. Available: 
https://files.eric.ed.gov/fulltext/EJ1089791.pdf.

[43] A. Suliman, "The Interference of Mother tongue/Native Language in One's English Language Speech Production," Int. J. english Educ., vol. 3, no. 3, 2014, [Online]. Available: http://ijee.org/yahoo_site_admin/assets/does/33.18 4152120.pdf.
[44] A. Fitri, "Pengaruh Bahasa Ibu Terhadap Pengguna Bahasa Asing: Kesalahan Transfer Secara Pragmatics," pp. 1-12, 2010.

[45] Y. Qomariana, I. Ayu, M. Puspani, and K. Sri, "Dalam Tulisan Mahasiswa Program Studi Sastra Inggris Fakultas Ilmu Budaya Universitas Udayana," 2019. 